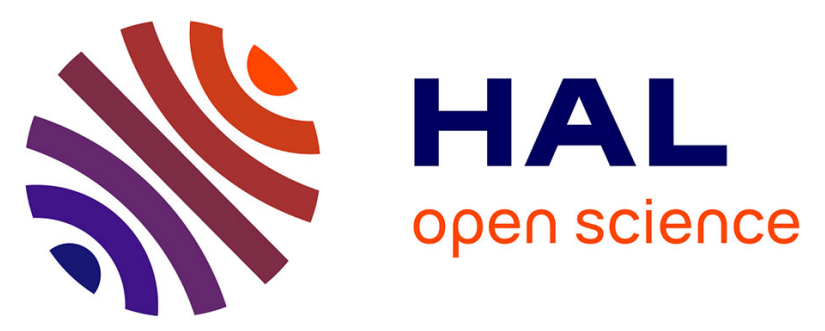

\title{
Contribution of hydrogen peroxide to the inhibition of Staphylococcus aureus by Lactococcus garvieae in interaction with raw milk microbial community
}

Céline C. Delbes, Géraud Dorchies, Zineddine Chaabna, Cecile C. Callon, Marie-Christine M.-C. Montel

\section{To cite this version:}

Céline C. Delbes, Géraud Dorchies, Zineddine Chaabna, Cecile C. Callon, Marie-Christine M.-C. Montel. Contribution of hydrogen peroxide to the inhibition of Staphylococcus aureus by Lactococcus garvieae in interaction with raw milk microbial community. Food Microbiology, 2010, 27 (7), pp.924932. 10.1016/j.fm.2010.05.031 . hal-02663600

\section{HAL Id: hal-02663600 \\ https://hal.inrae.fr/hal-02663600}

Submitted on 31 May 2020

HAL is a multi-disciplinary open access archive for the deposit and dissemination of scientific research documents, whether they are published or not. The documents may come from teaching and research institutions in France or abroad, or from public or private research centers.
L'archive ouverte pluridisciplinaire HAL, est destinée au dépôt et à la diffusion de documents scientifiques de niveau recherche, publiés ou non, émanant des établissements d'enseignement et de recherche français ou étrangers, des laboratoires publics ou privés. 


\title{
Contribution of hydrogen peroxide to the inhibition of Staphylococcus aureus by Lactococcus garvieae in interaction with raw milk microbial community
}

\author{
Céline Delbes-Paus*, Géraud Dorchies, Zineddine Chaabna, Cécile Callon, Marie-Christine Montel \\ Unité de Recherches Fromagères UR545, INRA, 20 Côte de Reyne, F-15000 Aurillac, France
}

\section{A R T I C L E I N F O}

\section{Article history:}

Received 18 December 2009

Received in revised form

26 May 2010

Accepted 27 May 2010

Available online 4 June 2010

\section{Keywords:}

Staphylococcus aureus

Lactococcus garvieae

Milk

Cheese

Hydrogen peroxide

Lactoperoxidase

\begin{abstract}
A B S T R A C T
The response of Staphylococcus aureus growth inhibition by Lactococcus garvieae to catalase and milk lactoperoxidase, and its efficiency in raw milk cheese were evaluated. S. aureus and L. garvieae were cocultivated in broth buffered at $\mathrm{pH}$ 6.8, and in raw, pasteurized and microfiltered milk, in presence and absence of catalase. Although $\mathrm{H}_{2} \mathrm{O}_{2}$ production by L. garvieae was detected only in agitated broth, the inhibition of $S$. aureus by L. garvieae was reduced by catalase both in static and shaking cultures by 2.7 $\log$, pasteurized milk $(\sim 0.7 \log )$, microfiltered milk $(\sim 0.6 \log )$ and raw milk $(\sim 0.2 \log )$. The growth of S. aureus alone in microfiltered milk was delayed compared with that in pasteurized milk and inhibition of $S$. aureus by L. garvieae was stronger in microfiltered milk. The inhibition of coagulase-positive staphylococci (CPS) by L. garvieae in raw milk cheese was similar to that in raw milk ( $\sim 0.8 \log )$, but weaker than that in pasteurized and microfiltered milks. L. garvieae also had an early antagonistic effect on the growth of several other microbial groups, which lastingly affected populations levels and balance during cheese ripening.
\end{abstract}

(c) 2010 Elsevier Ltd. All rights reserved.

\section{Introduction}

Staphylococcus aureus strains can produce staphylococcal enterotoxins (SEs), which have frequently been responsible for food poisoning associated with raw milk cheese in France (De Buyser et al., 2001), in other European countries (Haeghebaert et al., 2002) and in Brazil (Simeao do Carmo et al., 2002), and with reconstituted milk in Japan (Ikeda et al., 2005). To ensure the safety of raw milk cheeses the development of food borne pathogens must be controlled, in compliance with European regulations laying down the obligation to determine the presence of enterotoxins in cheese if the level of $S$. aureus is over $10^{5} \mathrm{CFUg}^{-1}$.

Safety has been greatly improved at the milk production stage by controlling mastitis in herds and applying hygienic practices (Sommerhauser et al., 2003; Chassagne et al., 2005). Bio-preservation strategies based on the addition of inhibitory bacterial strains may also be used to inhibit the growth of pathogens in cheese. Some members of raw milk complex microbial communities such as lacticacid bacteria (e.g., Lactococcus lactis, Lactococcus garvieae, Lactobacillus spp., Leuconostoc spp., and enterococci) could contribute to the control of $S$. aureus in cheese, not only by decreasing $\mathrm{pH}$ but also by

\footnotetext{
* Corresponding author. Tel.: +33 4714564 19; fax: +33 471456413 .

E-mail address: celine.delbes@clermont.inra.fr (C. Delbes-Paus).
}

producing bacteriocins (Arques et al., 2005) or $\mathrm{H}_{2} \mathrm{O}_{2}$ (Haines and Harmon, 1973; Ocana et al., 1999; Otero and Nader-Macias, 2006). L. garvieae is commonly isolated from raw milk and dairy products. L. garvieae strains have been reported to produce bacteriocin (garviecin; Villani et al., 2001) and bacteriocin-like substances that inhibit indicator strains of Listeria monocytogenes and L. innocua but also Lactobacillus sakei, Enterococcus faecium and E. mundtii (Corsetti et al., 2008), L. lactis and Pediococcus acidilactici (Sanchez et al., 2007). Alomar et al. (2008a,b) showed that L. garvieae inhibited S. aureus in microfiltered milk and in cheese made with pasteurized milk. Inhibition of S. aureus by L. garvieae in microfiltered milk has been shown to be due neither to acidification nor to competition for amino acids. A preliminary study in brain-heart infusion (Alomar, 2007) suggested that hydrogen peroxide may play a role in the inhibition of $S$. aureus by $L$. garvieae, although the determination of hydrogen peroxide production by L. garvieae using ABTS (2,2-azino-bis-3-ethylbenzthiazoline-6-sulfonic acid) (Yang and Ma, 2005) gave inconsistent results. If hydrogen peroxide is involved in the inhibition of S. aureus by L. garvieae, its efficiency in milk may be affected by the lactoperoxidase system (LPS), an antimicrobial system found in milk (Piard and Desmazeaud, 1991). To be functional, lactoperoxidase and thiocyanate, which occur naturally in milk, must be combined with a source of $\mathrm{H}_{2} \mathrm{O}_{2}$ (Kamau et al., 1990). The efficiency of $S$. aureus inhibition by L. garvieae may also depend on the interactions of both these organisms with the indigenous microflora of raw milk, which, among others, includes catalase-positive bacteria. 
The present work had two aims. One was to investigate the role of $\mathrm{H}_{2} \mathrm{O}_{2}$ in the inhibition of $\mathrm{S}$. aureus growth by L. garvieae and the interaction with milk lactoperoxidase. The other, with a view to exploiting the antistaphylococcal activities of $L$. garvieae in raw milk cheese, was to examine the efficiency of inhibition during cheese-making and ripening. In particular, the mutual effect of L. garvieae and the indigenous microbiota of raw milk on the inhibition was investigated.

\section{Material and methods}

\subsection{Strains and culture conditions}

L. garvieae N201 and S. aureus SA15, isolated from raw milk, were cultured as described by Alomar et al. (2008a). Cell concentrations in broths were determined by microscopy using a Petroff-Hausser cell.

\subsection{Co-culture of S. aureus and L. garvieae in brain-heart infusion}

(BHI) and sensitivity of $S$. aureus to hydrogen peroxide

S. aureus SA15 (150 CFU ml ${ }^{-1}$ ) was co-cultivated with L. garvieae $\mathrm{N} 201\left(10^{8} \mathrm{CFU} \mathrm{ml}^{-1}\right)$ in $40-\mathrm{ml}$ portions of BHI (Biokar Diagnostics, Pantin, France) in $100-\mathrm{ml}$ flasks incubated at $30^{\circ} \mathrm{C}$ for $24 \mathrm{~h}$, either under aerobic static or shaking (150 rpm) conditions (Table 1). BHI was buffered at pH 6.8 with phosphate buffer $\mathrm{KH}_{2} \mathrm{PO}_{4} / \mathrm{K}_{2} \mathrm{HPO}_{4}$ $0.1 \mathrm{~mol} \mathrm{l}^{-1}\left(\mathrm{KH}_{2} \mathrm{PO}_{4}\right.$, Prolabo; $\mathrm{K}_{2} \mathrm{HPO}_{4}$, Merck) to avoid the effect of decreasing $\mathrm{pH}$ values on the growth of $S$. aureus. Catalase from bovine liver (ref. C100, Sigma) was added at a final concentration of $4000 \mathrm{IU} \mathrm{ml}^{-1}$. Samples constituted by the whole content of one flask for each experimental condition were taken at time 0 and after $3,6,9$ and 24 h of incubation to determine S. aureus and L. garvieae counts and hydrogen peroxide concentrations.

In order to determine the sensitivity of S. aureus SA15 to hydrogen peroxide, this strain was inoculated at $150 \mathrm{CFU} \mathrm{ml} \mathrm{m}^{-1}$ in BHI containing from 0.5 to $5 \mathrm{mmol}^{-1}$ of hydrogen peroxide and incubated at $37{ }^{\circ} \mathrm{C}$ as the optimal temperature for growth of S. aureus, for $18 \mathrm{~h}$. S. aureus SA15 count after $18 \mathrm{~h}$ was determined and compared to that in a control assay without hydrogen peroxide.

\subsection{Co-culture of S. aureus and L. garvieae in raw,} high-temperature pasteurized and microfiltered milk

Bulk tank milk (120 L) was divided into 3 portions. The first part (1 L) was not treated (raw milk). The second part $(40 \mathrm{~L})$ was pasteurized at $80{ }^{\circ} \mathrm{C}$ for $15 \mathrm{~s}$. The third part $(70 \mathrm{~L})$ was separated into cream and skimmed milk. The raw cream was pasteurized at $80{ }^{\circ} \mathrm{C}$ for $15 \mathrm{~s}$. The skimmed milk was processed at $50{ }^{\circ} \mathrm{C}$ through the microfiltration unit equipped with a $1.2 \mu \mathrm{m}$-pore size ceramic membrane. The pasteurized cream was blended with the

\section{Table 1}

Production of hydrogen peroxide by L. garvieae N201 and effect of catalase on the inhibition of S. aureus SA15 by L. garvieae, in buffered Brain Heart Infusion (pH 6.8). ND, not determined.

\begin{tabular}{|c|c|c|c|c|c|c|c|c|c|c|}
\hline & \multirow[t]{2}{*}{$\begin{array}{l}\text { L. garvieae } \\
(\log \mathrm{CFU} / \mathrm{ml})\end{array}$} & \multirow[t]{2}{*}{$\begin{array}{l}\text { Catalase } \\
(\mathrm{IU} / \mathrm{ml})\end{array}$} & \multicolumn{4}{|c|}{$\begin{array}{l}\text { S. aureus } \\
\text { (log CFU/ml) } \\
\text { Time (h) }\end{array}$} & \multicolumn{4}{|c|}{$\begin{array}{l}\mathrm{H}_{2} \mathrm{O}_{2} \\
(\mathrm{mmol} / \mathrm{l}) \\
\text { Time }(\mathrm{h})\end{array}$} \\
\hline & & & 3 & 6 & 9 & 24 & 3 & 6 & 9 & 24 \\
\hline \multirow{3}{*}{ Static } & 0 & 0 & 2,83 & 4,48 & 5,77 & 7,28 & 0 & 0 & 0 & 0 \\
\hline & 8 & 0 & 2,48 & 3,00 & 4,04 & 4,57 & 0 & 0 & 0 & 0 \\
\hline & 8 & 4000 & ND & ND & ND & 7,30 & 0 & 0 & 0 & 0 \\
\hline \multirow{3}{*}{$\begin{array}{l}\text { Shaking } \\
\text { (150 RPM) }\end{array}$} & 0 & 0 & 2,72 & 4,32 & 5,70 & 8,36 & 0 & 0 & 0 & 0 \\
\hline & 8 & 0 & 2,48 & 2,30 & 3,60 & 4,60 & 0 & 1 & 1,4 & 1,6 \\
\hline & 8 & 4000 & ND & ND & ND & 7,34 & 0 & 0 & 0 & 0 \\
\hline
\end{tabular}

microfiltration permeate to obtain a protein:fat ratio equal to that in the raw whole milk.

Raw, pasteurized and microfiltered milks were each distributed in 40 -ml portions in $100-\mathrm{ml}$ flasks and allowed to settle at $33^{\circ} \mathrm{C}$, the average temperature of milk in the vat when starter cultures are added at the begining of the cheese-making process, in a non-agitated water bath. S. aureus (SA15) was added to all flasks at a concentration of $150 \mathrm{CFU} \mathrm{ml}{ }^{-1}$ of milk. L. garvieae (N201) was added at a concentration of $10^{8} \mathrm{CFU} \mathrm{ml} \mathrm{m}^{-1}$, as previously determined (Alomar et al., 2008a), to half of the flasks (Table 2). Catalase from bovine liver (ref. C100, Sigma, Saint-Louis, Missouri, USA) was added at final concentration of $4000 \mathrm{IU} \mathrm{ml}^{-1}$. Milk samples constituted by the whole content of one flask for each experimental condition were taken at time 0 and after 6 and $24 \mathrm{~h}$ of incubation. Subsamples were stored at $-20^{\circ} \mathrm{C}$ for microbiological analysis and to determine lactoperoxidase activity. The entire experimental design was repeated three times.

\subsection{Co-culture of S. aureus and L. garvieae in high-temperature pasteurized milk with or without lactoperoxidase}

Bulk tank milk was pasteurized at $80{ }^{\circ} \mathrm{C}$ for $15 \mathrm{~s}$, distributed in $20-\mathrm{ml}$ portions in $100-\mathrm{ml}$ flasks and allowed to settle at $33{ }^{\circ} \mathrm{C}$ in a non-agitated water bath. S. aureus (SA15) and L. garvieae (N201) were added respectively at a concentration of $150 \mathrm{CFU} \mathrm{ml}{ }^{-1}$ and of $10^{8} \mathrm{CFU} \mathrm{ml} \mathrm{m}^{-1}$ (see Table 3 for experimental design). Lactoperoxidase from bovine milk (ref. L2005, Sigma, Saint-Louis, Missouri, USA) was added at final concentration of $37 \mathrm{mg} \mathrm{l}^{-1}$, similar to what was found in raw milk in the previous assays. Three flasks for each experimental condition were taken at time 0 and after 6 and $24 \mathrm{~h}$ of incubation. Subsamples were stored at $-20{ }^{\circ} \mathrm{C}$ for microbiological analysis and to determine lactoperoxidase activity.

\subsection{Inoculation of L. garvieae in raw milk and cheese making}

Raw farm milk was collected and transferred to the experimental cheese plant (INRA, URF, Aurillac) within $15 \mathrm{~min}$. It was used to make 3 assay cheeses $(600 \mathrm{~g}$ ) inoculated with $L$. garvieae and 3 control cheeses without $L$. garvieae using an uncooked pressed cheese technology. Milk was placed into six 6-L vats and warmed to $33^{\circ} \mathrm{C}$. The commercial MY800 starter culture (Streptococcus thermophilus, Lactobacillus delbruekii subsp. lactis, and L. delbruekii subsp. bulgaricus) (Rhodia S.A., Paris La Défense, France) was inoculated in all vats $(0.6 \%, \mathrm{vol} / \mathrm{vol})$. L. garvieae (N201) was added to half the vats (Table 3 ) at a concentration of $10^{8} \mathrm{CFU} \mathrm{ml}{ }^{-1}$ of milk. Rennet was added to all vats at $1.51 \mathrm{~g} \mathrm{l}^{-1}$ (Beaugel $520 \mathrm{mg} / \mathrm{L}$ of chymosin). Coagulation proceeded for about $45 \mathrm{~min}$ and then the curd was cut, prepressed and placed in molds. Salt (26 g per cheese) was added and draining was completed under 3-bar pressure for $24 \mathrm{~h}$. The cheeses were coated with wax containing 1000 ppm of natamycin (Coquard, Villefranche sur Saône, France) to prevent the development of moulds and yeasts on the cheese surface. Then they were ripened in a ripening room at $10{ }^{\circ} \mathrm{C}, 96 \%$ relative humidity for 32 days. Samples were taken aseptically from the raw milk in each vat prior to the addition of the rennet, and from the cheeses (one quarter of each cheese) on days 1 , 8,16 and 32 . Cheese rind $(5 \mathrm{~mm})$ was discarded. Subsamples were stored at $4{ }^{\circ} \mathrm{C}$ and analysed within $24 \mathrm{~h}$ for their coagulase-positive staphylococci count and the remainder stored at $-20^{\circ} \mathrm{C}$ for further microbiological tests. The entire experimental design was repeated twice with raw milk from two different farms.

\subsection{Microbial analyses}

Milk and cheese samples were emulsified in sterile phosphate buffer 2\% (wt/vol) and blended with a Stomacher Lab Blender (Seward Medical, London, UK) for 4 min. All counts were performed 
Table 2

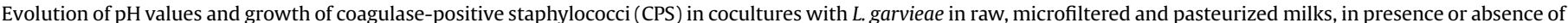

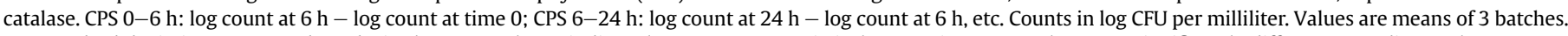

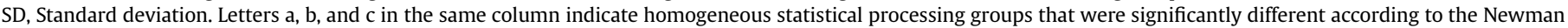
Keuls statistical test, with $\mathrm{A}<\mathrm{B}<\mathrm{C} .{ }^{*}, P, 0.05$; $^{* *}, P, 0.01$; ${ }^{* *}, P, 0.001$; NS, not significant.

\begin{tabular}{|c|c|c|c|c|c|c|c|c|c|c|c|c|c|c|c|c|}
\hline \multirow[t]{2}{*}{ Milk } & \multirow{2}{*}{$\begin{array}{l}\text { Catalase } \\
(\mathrm{IU} / \mathrm{ml})\end{array}$} & \multirow{2}{*}{$\begin{array}{l}\text { L. garvieae } \\
(\log \mathrm{CFU} / \mathrm{ml})\end{array}$} & \multicolumn{3}{|l|}{ pH 6 h } & \multicolumn{3}{|c|}{$\mathrm{pH} 24 \mathrm{~h}$} & \multicolumn{3}{|c|}{ CPS 0-6 h } & \multicolumn{3}{|c|}{ CPS 6-24 h } & \multicolumn{2}{|c|}{ CPS $0-24 \mathrm{~h}$} \\
\hline & & & Mean & SD & & Mean & SD & & Mean & SD & & Mean & SD & & Mean & SD \\
\hline Raw & 0 & 0 & 6,78 & 0,03 & $\mathrm{~b}$ & 4,57 & 0,33 & $a$ & 2,42 & 1,33 & $\mathrm{~d}$ & 1,09 & 1,06 & $\mathrm{~b}$ & 3,51 & 1,12 \\
\hline Raw & 0 & 8 & 6,71 & 0,06 & b & 4,73 & 0,38 & $\mathrm{a}$ & 1,41 & 0,22 & b & 1,22 & 1,06 & b & 2,63 & 1,24 \\
\hline Raw & 4000 & 0 & 6,76 & 0,01 & $\mathrm{~b}$ & 4,55 & 0,33 & $\mathrm{a}$ & 1,86 & 0,75 & c & 1,55 & 0,92 & b & 3,41 & 1,09 \\
\hline Raw & 4000 & 8 & 6,66 & 0,07 & $\mathrm{ab}$ & 4,69 & 0,39 & $a$ & 1,20 & 0,54 & b & 1,64 & 1,43 & b & 2,84 & 1,05 \\
\hline Pasteurized & 0 & 0 & 6,74 & 0,06 & $\mathrm{~b}$ & 6,03 & 0,33 & c & 1,79 & 0,41 & $\mathrm{~b}$ & 1,81 & 1,30 & b & 3,59 & 1,34 \\
\hline Pasteurized & 0 & 8 & 6,51 & 0,20 & $\mathrm{ab}$ & 5,60 & 0,20 & bc & $-0,05$ & 1,13 & $\mathrm{a}$ & 1,25 & 1,10 & b & 1,20 & 2,22 \\
\hline Pasteurized & 4000 & 0 & 6,73 & 0,05 & $\mathrm{~b}$ & 5,99 & 0,27 & c & 1,69 & 0,33 & b & 1,15 & 0,84 & b & 2,83 & 0,56 \\
\hline Pasteurized & 4000 & 8 & 6,45 & 0,22 & $\mathrm{a}$ & 5,40 & 0,26 & b & 0,45 & 0,58 & $a b$ & 1,42 & 1,01 & $\mathrm{~b}$ & 1,87 & 1,10 \\
\hline Microfiltered & 0 & 0 & 6,77 & 0,02 & $\mathrm{~b}$ & 6,62 & 0,02 & $\mathrm{e}$ & 0,44 & 0,94 & $a b$ & 3,78 & 0,38 & c & 4,21 & 0,55 \\
\hline Microfiltered & 0 & 8 & 6,61 & 0,09 & $\mathrm{ab}$ & 6,00 & 0,22 & c & 0,45 & 0,31 & $a b$ & 0,76 & 0,53 & a & 1,21 & 0,64 \\
\hline Microfiltered & 4000 & 0 & 6,75 & 0,04 & $\mathrm{~b}$ & 6,20 & 0,35 & $\mathrm{~d}$ & 0,82 & 0,77 & b & 2,61 & 1,67 & $\mathrm{~b}$ & 3,43 & 1,37 \\
\hline Microfiltered & 4000 & 8 & $\begin{array}{l}6,59 \\
* *\end{array}$ & 0,08 & $\mathrm{ab}$ & $\begin{array}{l}5,92 \\
* *\end{array}$ & 0,19 & bc & $\begin{array}{l}0,34 \\
* *\end{array}$ & 0,33 & $a b$ & $\begin{array}{l}1,50 \\
* *\end{array}$ & 0,90 & $\mathrm{~b}$ & $\begin{array}{l}1,84 \\
\text { NS }\end{array}$ & 0,89 \\
\hline
\end{tabular}

in duplicate either by manual plating for milk samples or using a Spiral plate system for cheese samples. Coagulase positive staphylococci were enumerated on Rabbit Plasma Fibrinogen Agar (RPFA) (EN ISO 6888-2). Mesophilic bacterial populations and thermophilic bacterial populations were enumerated on M17 agar (Terzaghi and Sandine, 1975) incubated at either $30^{\circ} \mathrm{C}$ or $42^{\circ} \mathrm{C}$. Lactococci were enumerated on Turner-Sandine-Elliker (TSE) agar (Turner et al., 1963) with nalidixic acid, facultatively heterofermentative (FH) lactobacilli on agar as described by Isolini et al. (1990), dextraneproducing leuconostocs on Mayeux-Sandine-Elliker (MSE) agar (Mayeux et al., 1962), enterococci on SB agar (Slanetz and Bartley, 1957), Pseudomonas on cetrimide-fucidin-cephalosporin (CFC) agar, Enterobacteriaceae on violet-red-bile-glucose (VRBG) agar and yeasts and moulds on oxytetracyclin-glucose agar (OGA). Samples were also spread on non selective media: Cheese Ripening Bacteria Medium (CRBM) described by Denis et al. (2001), Plate Count Agar supplemented with 1\% milk (PCAM) and Plate Count Agar supplemented with $1 \%$ milk, $5 \mathrm{mg} / \mathrm{l}$ vancomycin and $5 \mathrm{mg} / \mathrm{l}$ crystal violet as inhibitors of Gram-positive bacteria (PCAI). Both PCA media were incubated at $30{ }^{\circ} \mathrm{C}$ for $48 \mathrm{~h}$. All media were purchased from Biokar Diagnostics (Pantin, France).

The $\mathrm{pH}$ values of milk and cheese were determined with a 926 VTV pH meter with an Ingold 406 MX penetration electrode (Mettler-Toledo S.A., Viroflay, France).

\subsection{Quantification of L. garvieae in milk and cheese by quantitative $P C R$}

\subsubsection{Primer design - specificity}

The sequences of $16 \mathrm{~S}$ rRNA genes from L. garvieae (9 strains), 5 species of Lactococcus and 2 species of Enterococcus were aligned using Clustalw software. The $L$. garvieae $16 \mathrm{~S}$ rDNA sequence was then examined for the presence of specific regions for the detection of $L$ garvieae. Two primers having a size of less than 25 nucleotides, $20-80 \%$ of GC, less than $2 \mathrm{G}$ or $\mathrm{C}$ in the last five nucleotides in $3^{\prime}-$ end, for which there were at least 3 mismatches with sequences of other species, and which gave an amplicon size of less than $200 \mathrm{pb}$ were determined. Regions corresponding to gene positions 30 to 52 (rtLgFw $5^{\prime}$-GCAAGTCGAGCGATGATTAAAGA- $3^{\prime}$ ) and to gene position 160 to 185 (rtLgRev 5'-TTCAAATAAGAATCATGCGATTCTC-3') amplifying a fragment of $140 \mathrm{pb}$ were selected. These primers were validated using Primers Express software (Applied Biosystems).

The specificity of primer sequences was initially evaluated in silico using the Probe Check program of the Ribosomal Database Project (Cole et al., 2003). It was then confirmed experimentally by classical PCR on 15 species of Lactococcus, Leuconostoc, Enterococcus, Lactobacillus and Pediococcus. The primers were synthesized by Eurogentec.

\subsubsection{Estimation of the sensitivity of the method}

L. garvieae genomic DNA isolated from an overnight culture in $10 \mathrm{ml}$ of broth was serially diluted 10 -fold in water and $5 \mu \mathrm{l}$ of the dilution were then subjected to real-time PCR amplification (conditions described below). All assays were performed in duplicate and the average values were used to determine the threshold cycle $(\mathrm{Ct})$. There was a linear relationship between the $\mathrm{Ct}$ and the logarithm of CFU/g (correlation coefficient $R^{2}$ of the standard curves was 0.993$)$. The amplification efficiency calculated $\left(E=10^{-1 / \text { slope }}\right)$ was 1.98 . The detection limit of the method was close to $10^{3} \mathrm{CFU} / \mathrm{g}$ and the amplification was linear over $5 \mathrm{log}$. Analysis of the melting curve showed a specific amplified product and no peak was observed with the controls in which all required reagents but no

Table 3

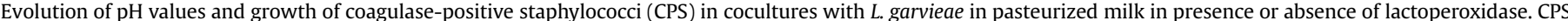

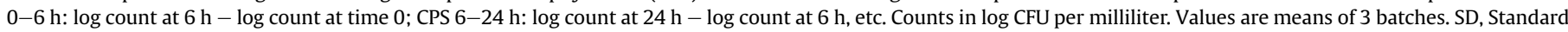

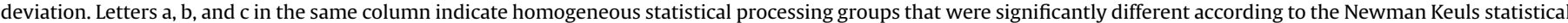
test, with $\mathrm{A}<\mathrm{B}<\mathrm{C} .{ }^{*}, P, 0.05$; $^{* *}, P, 0.01{ }^{* * *}, P, 0.001$; NS, not significant.

\begin{tabular}{|c|c|c|c|c|c|c|c|c|c|c|c|c|c|c|c|c|}
\hline \multirow{2}{*}{$\begin{array}{l}\text { Lactoperoxidase } \\
\left(\mathrm{mg} \mathrm{l}^{-1}\right)\end{array}$} & \multirow{2}{*}{$\begin{array}{l}\text { L. garvieae } \\
\left(\log \mathrm{CFU} \mathrm{ml^{-1 }}\right)\end{array}$} & \multicolumn{3}{|c|}{$\mathrm{pH} 6 \mathrm{~h}$} & \multicolumn{3}{|c|}{$\mathrm{pH} 24 \mathrm{~h}$} & \multicolumn{3}{|c|}{ CPS 0-6 h } & \multicolumn{3}{|c|}{ CPS 6-24h } & \multicolumn{3}{|c|}{ CPS $0-24 \mathrm{~h}$} \\
\hline & & Mean & SD & & Mean & SD & & Mean & SD & & Mean & SD & & Mean & SD & \\
\hline 0 & 0 & 6,75 & 0,01 & $\mathrm{~b}$ & 6,39 & 0,01 & $\mathrm{~b}$ & 2,33 & 0,10 & c & 3,48 & 0,08 & $\mathrm{~b}$ & 5,82 & 0,08 & c \\
\hline 0 & 8 & 6,35 & 0,01 & $\mathrm{a}$ & 5,69 & 0,02 & $\mathrm{a}$ & $-1,20$ & 0,35 & a & 0,80 & 0,35 & $\mathrm{a}$ & $-0,40$ & 0,35 & $\mathrm{a}$ \\
\hline 37 & 0 & 6,73 & 0,01 & b & 6,16 & 0,33 & $\mathrm{~b}$ & 2,29 & 0,04 & c & 3,04 & 0,46 & $\mathrm{~b}$ & 5,33 & 0,50 & c \\
\hline 37 & 8 & $\begin{array}{l}6,36 \\
* *\end{array}$ & 0,01 & $\mathrm{a}$ & $\begin{array}{l}5,57 \\
* *\end{array}$ & 0,16 & $\mathrm{a}$ & $\begin{array}{l}0,14 \\
* *\end{array}$ & 0,05 & b & $\begin{array}{l}1,22 \\
* *\end{array}$ & 0,26 & $\mathrm{a}$ & $\begin{array}{l}1,36 \\
* *\end{array}$ & 0,24 & $\mathrm{~b}$ \\
\hline
\end{tabular}


DNA were added. The method was then validated by quantifying L. garvieae inoculated at different concentrations in microfiltered milk. A good match was observed between real-time PCR quantification and theoretic values in milk.

\subsubsection{DNA extraction from milk and cheese samples}

$10 \mathrm{ml}$ of milk or $1 \mathrm{~g}$ of cheese were subjected to DNA extraction according to protocols described by Callon et al. (2007) for the milk, and by Duthoit et al. (2003) for the cheeses, using Phase-Lock tubes (Eppendorf) for the phenol/chloroform extraction steps.

\subsubsection{Real-time PCR conditions}

SYBR Green PCR amplifications were performed using an ABI Prism 7700 (Applied Biosystems) in a $25 \mu$ l final volume containing $5 \mu$ of DNA sample or standard, $2 \mathrm{mM} \mathrm{MgCl}_{2}, 200 \mathrm{mM}$ of each primer, $2 \mathrm{mM}$ dNTP mix, Sybr Green PCR buffer $1 \times$, Ampli Taq Gold polymerase $5 \mathrm{U} / \mu \mathrm{l}$. Amplification consisted of an initial hold at $95^{\circ} \mathrm{C}$ for $10 \mathrm{~min}$ followed by 40 cycles of $95^{\circ} \mathrm{C}$ for $15 \mathrm{~s}$ and $61^{\circ} \mathrm{C}$ for $1 \mathrm{~min}$. Standard and 1/10 diluted samples were run on the same plate and analysed in duplicate. Threshold cycle $(\mathrm{Ct})$ values were determined by the SDS software (Applied Biosystems).

\subsection{Determination of hydrogen peroxide production in BHI}

The concentration of $\mathrm{H}_{2} \mathrm{O}_{2}$ during cell growth in buffered $\mathrm{BHI}$ was determined as described by Batdorj et al. (2007) with slight modifications. First a $100-\mu \mathrm{l}$ aliquot of culture supernatant $(9600 \mathrm{~g}$, $4{ }^{\circ} \mathrm{C}, 10 \mathrm{~min}$ ) was mixed with a solution composed of $750 \mu \mathrm{l}$ of phosphate buffer $\mathrm{Na}_{2} \mathrm{HPO}_{4} / \mathrm{NaH}_{2} \mathrm{PO}_{4}(0.1 \mathrm{M}, \mathrm{pH} 7), 100 \mu \mathrm{l}$ of $4-$ aminoantipyrine solution (4 $\mathrm{mg} \mathrm{ml} \mathrm{ml}^{-1}$, amino-2,3-dimethyl-1phenyl-3-pyrazolin-5-one, Sigma) and $20 \mu$ of water-saturated phenol. Then $30 \mu \mathrm{l}$ of horseradish peroxidase type VI-A (Sigma, $1000 \mathrm{U} \mathrm{ml}^{-1}$ solution in sodium phosphate buffer $\mathrm{pH} \mathrm{6)}$ ) were added, the reaction was allowed to proceed for $2 \mathrm{~min}$ and the change in absorbance was measured at $505 \mathrm{~nm}$. The hydrogen peroxide was quantified using a standard curve determined with $\mathrm{H}_{2} \mathrm{O}_{2}$ solutions in sodium phosphate buffer at concentrations ranging from 1.5 to $100 \mu \mathrm{mol} \mathrm{l}^{-1}$.

\subsection{Determination of hydrogen peroxide in milk}

The method based on 4-aminoantipyrine (Batdorj et al., 2007) gave inconsistent results for hydrogen peroxide analysis in milk. Instead, the method used was derived from that described by Ferrier et al. (1970). Hydrogen peroxide standards $(0,125,250,500$ and $1000 \mu \mathrm{M}$ ) were prepared by adding $1 \mathrm{ml}$ of water containing the appropriate amount of hydrogen peroxide to $9 \mathrm{ml}$ of whole milk previously heated to $80^{\circ} \mathrm{C}$ for $5 \mathrm{~min}$. For $\mathrm{H}_{2} \mathrm{O}_{2}$ determination, $4 \mathrm{ml}$ of milk were added to $4 \mathrm{ml}$ of $2 \%$ trichloro-acetic acid, well mixed and filtered through Whatman no. 42 filter paper. One hundred $\mu \mathrm{l}$ of Titanium (IV) chloride solution $0.09 \mathrm{M}$ in $20 \% \mathrm{HCl}$ (Aldrich) were added to a $1-\mathrm{ml}$ aliquot of the filtrate and the absorbance was measured against a reagent blank (filtrate $+\mathrm{TiCl}_{4}$ ) at $415 \mathrm{~nm}$ on a Hitachi U-2000 spectrophotometer. The detection level for hydrogen peroxide in milk using this method was $100 \mu \mathrm{M}$.

\subsection{Determination of lactoperoxidase enzyme activity in milk}

The LP activity of the milk samples was determined using the ABTS (Sigma, ref. A 9941) assay as described by Kumar and Bathia (1998). Since several of the milk samples coagulated during incubation, all milk samples were homogenized by vigorously shaking for $10 \mathrm{~s}$, diluted to $1 / 250$ in phosphate buffer $(0.1 \mathrm{M}, \mathrm{pH} 6)$ containing $0.1 \%$ gelatin (PBSG), and filtered through a Whatmann $\mathrm{n}^{\circ} 42$ filter paper. The change in the absorbance readings at $412 \mathrm{~nm}$ for $2 \mathrm{~min}$ was recorded using a Hitachi U-2000 spectrophotometer. The enzyme concentration was calculated using a standard curve determined with solutions of commercial lactoperoxidase (Sigma, ref. L2005) in boiled milk at concentrations ranging from 5 to $50 \mathrm{mg} \mathrm{l}^{-1}$.

\subsection{Determination of galactose, lactose, lactic and acetic acid contents of cheese}

Galactose, lactose, L-Lactate, D-lactate and acetic acid contents were determined using enzymatic method as recommended with R-Biopharm kits (R-Biopharm AG, Darmstadt, Germany). Results were expressed in $\mathrm{g}$ per $\mathrm{kg}$ of cheese dry weight.

\subsection{Statistical analyses}

Standard analyses of variance were performed to assess the effect of the milk treatments, the inoculation with L. garvieae and the addition of catalase on $\mathrm{pH}$ values and microbial counts using Statistica software (Statsoft, version 6, Maisons-Alfort, France). Where the differences were significant, a Newman-Keuls test was performed. Statistical correlations were carried out by the Pearson's correlation coefficient. A stepwise multiple linear regression was performed for milks inoculated with $L$. garvieae to rank the parameters (milk treatment, $\mathrm{pH}$, catalase) which can explain the growth of coagulase-positive staphylococci between 0 and $6 \mathrm{~h}$, and between 6 and $24 \mathrm{~h}$ of incubation.

\section{Results and discussion}

\subsection{Potential role of hydrogen peroxide in the inhibition of S. aureus by L. garvieae in brain heart infusion (BHI)}

S. aureus growth was inhibited by L. garvieae in buffered BHI in both static and shaking conditions (Table 1 ). S. aureus count after $24 \mathrm{~h}$ in broth inoculated with $L$. garvieae was lower than the corresponding control cultures by $\sim 2.7 \log$ in static cultures and by $\sim 3.8 \mathrm{log}$ in shaken cultures. This inhibition could not be explained by $\mathrm{pH}$ values since they remained above 6.7 in the buffered broth. The detection level for hydrogen peroxide in buffered BHI using the method described by Batdorj et al. (2007) was $1.5 \mu \mathrm{M}$. Hydrogen peroxide was only detected in aerated, shaken cultures where it reached up to $1.6 \mathrm{mM}$ after $24 \mathrm{~h}$ of incubation. The addition of catalase together with $L$. garvieae released inhibition by 2.7 log both in static cultures (100\% reduction) and shaking cultures (72\%).

The sensitivity of S. aureus SA15 to concentrations of hydrogen peroxide from 0.5 to $5 \mathrm{mM}$ was determined in buffered $\mathrm{BHI}$ incubated at $37{ }^{\circ} \mathrm{C}$. The $S$. aureus SA15 count after $18 \mathrm{~h}$ was 7.3 $\log$ CFU ml ${ }^{-1}$ in the control assay. It was $0.3 \log$ lower in presence of $0.5 \mathrm{mM}$ of hydrogen peroxide and $2 \log$ lower in presence of $1 \mathrm{mM}$ of hydrogen peroxide. S. aureus populations were below the detection level $\left(10 \mathrm{CFU} \mathrm{ml}{ }^{-1}\right)$ after $18 \mathrm{~h}$ with hydrogen peroxide concentrations of $2-5 \mathrm{mM}$.

It is striking that $S$. aureus growth was inhibited by L. garvieae in static cultures although no $\mathrm{H}_{2} \mathrm{O}_{2}$ was detected in these conditions. Results from literature show that Lactobacillus crispatus produced up to $2.8 \mathrm{mM}$ of $\mathrm{H}_{2} \mathrm{O}_{2}$ in agitated culture but no detectable amount of this metabolite in aerobic non-agitated cultures (Ocana et al., 1999). On the other hand, cells of Streptococcus gordonii and Lactobacillus delbrueckii subsp. bulgaricus still synthetized $\mathrm{H}_{2} \mathrm{O}_{2}$ when grown statically, although at a lower rate than cells which were aerated during growth (Marty-Teysset et al., 2000; Barnard and Stinson, 1999). These results suggest that the need for agitating LAB cultures in order to detect $\mathrm{H}_{2} \mathrm{O}_{2}$ production in culture medium could be dependent on species or strain. Moreover, hydrogen peroxide at low concentrations is quite unstable and may react with 
other microbial metabolic end products or intermediates (Gilliland and Speck, 1969), making the determination of $\mathrm{H}_{2} \mathrm{O}_{2}$ production difficult. Therefore, addition of catalase is commonly used as an indirect method of determining the involvement of $\mathrm{H}_{2} \mathrm{O}_{2}$ in inhibition (Regev-Yochay et al., 2006). In our study, inhibition of $S$. aureus by $L$. garvieae was reduced when catalase was added to BHI, both in static and shaking conditions. These results suggested that $\mathrm{H}_{2} \mathrm{O}_{2}$ was involved, either directly or via other oxygen derivatives or reaction products, in the inhibition occuring in BHI both in static and shaking conditions.

\subsection{Response of the inhibition of S. aureus by L. garvieae in milk to catalase and lactoperoxidase}

The aims of this part of the work were to confirm the role of $\mathrm{H}_{2} \mathrm{O}_{2}$ in the inhibition of S. aureus growth by L. garvieae in milk and to evaluate it's interaction with milk enzymatic activities and microbiota. For that purpose, milk was either heated to eliminate heat-sensitive enzymatic activities and microbial populations, or microfiltered to eliminate the latter while preserving enzymatic activities. Co-cultures of $S$. aureus and L. garvieae in treated and untreated milks, in presence or absence of catalase were then studied.

Microfiltration did not affect lactoperoxidase (LP) activity, which was similar to that in raw milk $\left(\sim 37 \mathrm{mg} \mathrm{l}^{-1}\right)$, whereas hightemperature pasteurization inactivated LP.

Total flora counted on PCA medium was below the detection limit (20 CFU ml ${ }^{-1}$ ) both in microfiltered and pasteurized milks. In raw milk, total flora count was $4 \pm 0.25 \log$ CFU ml ${ }^{-1}$ and coagulase-positive staphylococci count was $2 \pm 0.4 \log \mathrm{CFU} \mathrm{m}{ }^{-1}$.

Table 2 shows the growth of coagulase-positive staphylococci (CPS) in cocultures with L. garvieae N201 in raw, microfiltered, pasteurized milks, in presence and absence of catalase. Coagulasepositive staphylococci growth in absence of $L$. garvieae and of catalase was delayed in microfiltered milk, compared to that in pasteurized and raw milks.

In absence of catalase, CPS growth was inhibited by L. garvieae in all milks but inhibition differed with time and milk treatment. Between 0 and $6 \mathrm{~h}$, the strongest inhibition of $S$. aureus growth by L. garvieae was observed in pasteurized milk $(\sim 1.8 \mathrm{log}$ difference with the control). Over $24 \mathrm{~h}$, growth of CPS ( $\sim 4.2 \mathrm{log})$ and relative inhibition $(\sim 3 \log )$ were the strongest in microfiltered milk, whereas relative inhibition by L. garvieae ( $\sim 1 \log$ ) was the weakest in raw milk.

No significant difference between raw, pasteurized and microfiltered milks was found in the L. garvieae counts, which ranged from 8.5 to $9 \log$ CFU ml ${ }^{-1}$ after $6 \mathrm{~h}$ and from 8.6 to $9.3 \log \mathrm{CFU} \mathrm{ml}^{-1}$ after $24 \mathrm{~h}$.

No hydrogen peroxide was detected in milk inoculated with L. garvieae or in control milk at any time. However, S. aureus growth between 0 and $6 \mathrm{~h}$ in pasteurized milk supplemented with $L$. garvieae and catalase was significantly higher $(0.5 \mathrm{log})$ than in pasteurized milk inoculated with $L$. garvieae alone. Similarly, S. aureus growth between 6 and $24 \mathrm{~h}$ in microfiltered milk supplemented with $L$. garvieae and catalase was significantly higher $(0.7 \mathrm{log})$ than in microfiltered milk inoculated with $L$. garvieae alone. Over $24 \mathrm{~h}$, the addition of catalase partially released inhibition of $S$. aureus by L. garvieae in pasteurized milk (by $\sim 0.7 \mathrm{log}$, $28 \%)$, in microfiltered milk ( $\sim 0.6 \log , 21 \%)$ and in raw milk $(\sim 0.2$ $\log , 24 \%$ ). These results could not be explained by a direct positive effect of catalase on S. aureus growth since in absence of $L$. garvieae, catalase reduced $S$. aureus growth over $24 \mathrm{~h}$ in pasteurized and microfiltered milks by $0.7 \mathrm{log}$ compared to the control milks (Table 2). Alternatively, they suggested that $\mathrm{H}_{2} \mathrm{O}_{2}$ or derivatives could be involved in the inhibition of $S$. aureus by L. garvieae in milk.
At time 0 , no significant difference in $\mathrm{pH}$ values was observed between raw, pasteurized and microfiltered milks inoculated or not with L. garvieae and/or catalase (data not shown). After $6 \mathrm{~h}$ of incubation, average $\mathrm{pH}$ values in all milks inoculated with $L$. garvieae were significantly lower (by 0,1 to $0.4 \mathrm{pH}$ units) than those in control milks (Table 2). They differed with milk treatment and ranged between 6.45 in pasteurized milk and 6.78 in raw milk. However, data from the literature (Le Marc et al., 2009; Sutherland et al., 1994) as well as data inferred from the model described by Alomar et al. (2008a) suggest that such pH values would not markedly affect the growth of $S$. aureus and could not fully explain the inhibition of $S$. aureus growth in milk within the first $6 \mathrm{~h}$. After $24 \mathrm{~h}, \mathrm{pH}$ values were lowest in raw milk (below 4.8) irrespective of the presence or absence of $L$. garvieae. Average $\mathrm{pH}$ values in pasteurized and microfiltered milks ranged between 5.3 and 6.6 and were significantly lower (by 0,1 to $0.5 \mathrm{pH}$ units) in inoculated milks than in controls.

In the present study the microfiltered and raw milks had similar LP activities and differed mainly by the presence of natural milk flora in raw milk. In absence of $L$. garvieae N201, coagulase-positive staphylococci grew more rapidly between 0 and $6 \mathrm{~h}$ in raw milk than in microfiltered milk. Since no differentiation was made between the native CPS populations present in raw milk and the inoculated strain, this result may be due to a better adaptation of wild populations of CPS present in raw milk than the inoculated SA15 strain. Inhibition of CPS growth by L. garvieae was observed both in microfiltered and raw milks, but was less important in raw milk. Addition of catalase also reduced inhibition less effectively in raw milk. These results may be due to a lower sensitivity of native CPS populations to $\mathrm{H}_{2} \mathrm{O}_{2}$ or to an antagonistic effect of the raw milk microbial community on the inhibitory activity of L. garvieae. Finally, coagulase-positive staphylococci growth between 6 and 24 h, in absence of L. garvieae N201, was weaker in raw milk than in microfiltered milk. This result suggested that the indigenous microbial community of raw milk had an antagonistic effect against CPS, possibly via acidification, since $\mathrm{pH}$ values were below 4.8 in raw milk after $24 \mathrm{~h}$.

Both HT pasteurization and microfiltration drastically reduced the indigenous milk flora. HT pasteurized and microfiltered milks may differ in terms of heat-sensitive activities such as the natural lactoperoxidase or catalase activity of milk. Lactoperoxidase was completely deactivated after HT pasteurization of milk at $80^{\circ} \mathrm{C}$ for 15 s, as found by Barrett et al. (1999). In our study, whereas the evolution of $L$. garvieae counts did not differ between the pasteurized and microfiltered milks, the delay in S. aureus growth alone in microfiltered milk but not in pasteurized milk may be due to a heatsensitive bacteriostatic compound present in microfiltered milk and absent in pasteurized milk. Furthermore, inhibition of $S$. aureus by L. garvieae was observed both in pasteurized and in microfiltered milks but was stronger in microfiltered milk. To determine whether these differences may result from lactoperoxidase activity, the response of the inhibition of S. aureus by L. garvieae in HT-pasteurized milk to addition of commercial lactoperoxidase was then studied. Table 3 shows the growth of S. aureus alone or in coculture with L. garvieae, in presence or absence of LP $\left(37 \mathrm{mg} \mathrm{l}^{-1}\right)$. Growth of S. aureus alone and inhibition by L. garvieae (Table 3 ) in absence of LP were higher than those observed in the first set of experiment with pasteurized milk (Table 2). This may result from differences in the biochemical composition of the milk used. S. aureus growth in absence of $L$. garvieae was not significantly affected by the addition of LP during the first $6 \mathrm{~h}$ but was reduced by 0.5 log over $24 \mathrm{~h}$ compared to the control milks. In co-cultures with $L$. garvieae, addition of LP kept $S$. aureus counts fairly stable between 0 and $6 \mathrm{~h}$ whereas they droped down below the initial inoculum $(\sim-1.2 \log )$ in pasteurized milk inoculated with L. garvieae alone. Over $24 \mathrm{~h}$, the addition of LP in pasteurized milk partially released inhibition of S. aureus by $L$. garvieae by $\sim 1.7 \log (27 \%)$. This assay did not 
Table 4

Microbial counts in raw milk cheeses with or without $L$. garvieae. Counts in log CFU per milliliter in milk and in log CFU per gram in cheese. Values are the means of 6 batches. SD, Standard deviation. Letters a, b, and $\mathrm{c}$ in the same column indicate homogeneous statistical processing groups that were significantly different according to the Newman Keuls statistical test, with $\mathrm{A}<\mathrm{B}<\mathrm{C}$. ${ }^{*}, P, 0.05 ;{ }^{* *}, P, 0.01 ; * * *, P, 0.001$.

\begin{tabular}{|c|c|c|c|c|c|c|c|c|c|c|c|c|c|c|c|c|c|c|c|}
\hline \multirow{3}{*}{$\begin{array}{l}\text { L. garvieae } \\
(\log \mathrm{CFU} / \mathrm{ml})\end{array}$} & \multirow{3}{*}{$\begin{array}{l}\text { Time } \\
\text { (days) }\end{array}$} & \multicolumn{3}{|c|}{ RPF C +} & \multicolumn{3}{|c|}{ RPF C- } & \multicolumn{3}{|l|}{ SB } & \multicolumn{3}{|c|}{ MSE D+ } & \multicolumn{3}{|l|}{ CFC } & \multicolumn{3}{|c|}{ Turner } \\
\hline & & \multicolumn{3}{|c|}{$\begin{array}{l}\text { Coagulase positive } \\
\text { staphylococci }\end{array}$} & \multicolumn{3}{|c|}{$\begin{array}{l}\text { Gram }+ \text { catalase }+ \\
\text { bacteria }\end{array}$} & \multicolumn{3}{|c|}{ Enterococci } & \multicolumn{3}{|c|}{$\begin{array}{l}\text { Dextrane-producing } \\
\text { leuconostoc }\end{array}$} & \multicolumn{3}{|c|}{ Pseudomonas } & \multicolumn{3}{|c|}{ Lactococcus } \\
\hline & & Mean & SD & & Mean & SD & & Mean & SD & & Mean & SD & & Mean & SD & & Mean & SD & \\
\hline 0 & 0 & 2,92 & 0,29 & $\mathrm{a}$ & 3,49 & 0,15 & $a$ & 2,24 & 0,10 & $a$ & 1,70 & 0,45 & $\mathrm{a}$ & 2,38 & 0,14 & $a$ & 3,56 & 0,27 & $\mathrm{a}$ \\
\hline 8 & 0 & 2,95 & 0,30 & $\mathrm{a}$ & 3,39 & 0,22 & $\mathrm{a}$ & 2,11 & 0,33 & $\mathrm{a}$ & 1,48 & 0,28 & $\mathrm{a}$ & 2,50 & 0,38 & $\mathrm{a}$ & 7,31 & 0,53 & $\mathrm{~d}$ \\
\hline 0 & 1 & 5,35 & 0,73 & c & 4,75 & 1,03 & b & 5,22 & 0,33 & c & 5,36 & 0,42 & c & 2,75 & 0,49 & $a$ & 6,55 & 0,20 & $\mathrm{~b}$ \\
\hline 8 & 1 & 4,35 & 0,66 & $\mathrm{~b}$ & 4,17 & 0,32 & $a b$ & 4,55 & 0,23 & $\mathrm{~b}$ & 4,60 & 0,30 & $\mathrm{~b}$ & 2,31 & 0,19 & $\mathrm{a}$ & 8,17 & 0,60 & ef \\
\hline 0 & 8 & 4,28 & 0,49 & b & 4,24 & 0,27 & $a b$ & 5,13 & 0,25 & c & 7,23 & 0,20 & e & 2,61 & 0,89 & $\mathrm{a}$ & 7,97 & 0,28 & e \\
\hline 8 & 8 & 3,46 & 0,25 & $\mathrm{a}$ & 3,82 & 0,25 & $\mathrm{a}$ & 4,43 & 0,14 & $\mathrm{~b}$ & 6,49 & 0,59 & $\mathrm{~d}$ & 2,34 & 0,07 & $\mathrm{a}$ & 8,29 & 0,33 & ef \\
\hline 0 & 16 & 3,96 & 0,51 & $\mathrm{~b}$ & 3,98 & 0,24 & $a b$ & 5,19 & 0,22 & c & 7,91 & 0,22 & $\mathrm{~g}$ & 2,89 & 0,76 & a & 8,17 & 0,08 & ef \\
\hline 8 & 16 & 3,17 & 0,21 & $\mathrm{a}$ & 3,74 & 0,53 & & 4,51 & 0,15 & $\mathrm{~b}$ & 7,37 & 0,63 & ef & 2,34 & 0,07 & $\mathrm{a}$ & 8,62 & 0,26 & f \\
\hline 0 & 32 & 3,39 & 0,50 & $\mathrm{a}$ & 3,73 & 0,70 & $\mathrm{a}$ & 5,32 & 0,14 & c & 7,79 & 0,22 & $\mathrm{f}$ & 3,89 & 0,81 & b & 6,89 & 0,35 & c \\
\hline 8 & 32 & $\begin{array}{l}3,23 \\
* *\end{array}$ & 0,27 & $\mathrm{a}$ & $\begin{array}{l}3,72 \\
* *\end{array}$ & 1,12 & $\mathrm{a}$ & $\begin{array}{l}4,67 \\
* *\end{array}$ & 0,12 & $\mathrm{~b}$ & $\begin{array}{l}7,66 \\
* *\end{array}$ & 0,18 & $\mathrm{f}$ & $\begin{array}{l}3,29 \\
* *\end{array}$ & 1,07 & $\mathrm{a}$ & $\begin{array}{l}8,45 \\
* *\end{array}$ & 0,25 & ef \\
\hline \multirow{3}{*}{$\begin{array}{l}\text { L. garvieae } \\
(\log \mathrm{CFU} / \mathrm{ml})\end{array}$} & \multirow{3}{*}{$\begin{array}{l}\text { Time } \\
\text { (days) }\end{array}$} & \multirow{2}{*}{\multicolumn{3}{|c|}{$\begin{array}{l}\text { FH } \\
\text { Facultative } \\
\text { heterofermentative } \\
\text { Lactobacilli }\end{array}$}} & \multicolumn{3}{|c|}{$\mathrm{PCA}+\mathrm{I}$} & \multicolumn{3}{|l|}{ CRBM } & \multicolumn{3}{|l|}{ OGA M } & \multicolumn{3}{|l|}{ OGAL } & \multicolumn{3}{|l|}{ VRBG } \\
\hline & & & & & \multicolumn{3}{|c|}{$\begin{array}{l}\text { Gram-negative } \\
\text { bacteria }\end{array}$} & \multicolumn{3}{|c|}{$\begin{array}{l}\text { Gram }+ \text { catalase }+ \\
\text { bacteria and } \\
\text { Enterococci }\end{array}$} & \multicolumn{3}{|c|}{ Moulds } & \multicolumn{3}{|l|}{ Yeasts } & $\overline{\text { Entero }}$ & eriaceae & \\
\hline & & $\overline{\text { Mean }}$ & SD & & $\overline{\text { Mean }}$ & SD & & Mean & SD & & Mean & SD & & $\overline{\text { Mean }}$ & SD & & $\overline{\text { Mean }}$ & SD & \\
\hline 0 & 0 & 2,52 & 0,14 & $\mathrm{a}$ & 1,96 & 0,65 & $\mathrm{ab}$ & 3,27 & 0,28 & $a$ & 1,67 & 0,64 & $\mathrm{a}$ & 2,07 & 0,29 & $\mathrm{a}$ & 1,00 & 0,00 & $\mathrm{a}$ \\
\hline 8 & 0 & 2,51 & 0,21 & $\mathrm{a}$ & 1,84 & 0,70 & $\mathrm{a}$ & 3,30 & 0,29 & $\mathrm{a}$ & 1,64 & 0,71 & $\mathrm{a}$ & 1,94 & 0,21 & $\mathrm{a}$ & 1,00 & 0,00 & $\mathrm{a}$ \\
\hline 0 & 1 & 5,05 & 0,42 & c & 3,71 & 0,44 & d & 4,96 & 0,27 & d & 2,97 & 0,34 & b & 3,30 & 0,35 & $\mathrm{~b}$ & 2,63 & 0,38 & $\mathrm{~d}$ \\
\hline 8 & 1 & 4,22 & 0,52 & $\mathrm{~b}$ & 2,67 & 0,43 & $\mathrm{bc}$ & 4,41 & 0,12 & $\mathrm{bc}$ & 2,86 & 0,36 & $\mathrm{~b}$ & 3,10 & 0,33 & $\mathrm{~b}$ & 1,51 & 0,65 & $a b$ \\
\hline 0 & 8 & 6,45 & 0,70 & d & 3,59 & 0,53 & $\mathrm{~d}$ & 5,20 & 0,72 & de & 3,11 & 0,83 & b & 4,28 & 0,65 & $\mathrm{~d}$ & 2,23 & 0,27 & c \\
\hline 8 & 8 & 6,28 & 0,56 & d & 2,63 & 0,48 & $\mathrm{bc}$ & 4,20 & 0,14 & $\mathrm{~b}$ & 2,83 & 0,44 & $\mathrm{~b}$ & 3,20 & 0,28 & $\mathrm{~b}$ & 1,38 & 0,25 & $a b$ \\
\hline 0 & 16 & 7,15 & 0,22 & e & 2,70 & 0,21 & $\mathrm{bc}$ & 5,35 & 0,43 & e & 3,21 & 0,45 & b & 4,09 & 0,49 & $\mathrm{~cd}$ & 1,59 & 0,54 & $\mathrm{~b}$ \\
\hline 8 & 16 & 6,66 & 0,24 & d & 2,83 & 0,40 & c & 4,96 & 0,37 & d & 3,33 & 0,06 & b & 3,61 & 0,29 & bc & 1,08 & 0,19 & $\mathrm{a}$ \\
\hline 0 & 32 & 7,95 & 0,29 & f & 2,54 & 0,49 & $\mathrm{bc}$ & 4,60 & 0,22 & $\mathrm{~cd}$ & 3,67 & 0,83 & b & 4,11 & 0,35 & $\mathrm{~cd}$ & 1,00 & 0,00 & $\mathrm{a}$ \\
\hline 8 & 32 & $\begin{array}{l}7,79 \\
* * *\end{array}$ & 0,24 & $\mathrm{f}$ & $\underset{* *}{2,77}$ & 0,81 & $\mathrm{bc}$ & $\underset{*}{4,76}$ & 0,79 & $\mathrm{~cd}$ & $\underset{* *}{3,44}$ & 0,92 & $\mathrm{~b}$ & $\begin{array}{l}3,94 \\
* *\end{array}$ & 0,66 & $\mathrm{~cd}$ & $\begin{array}{l}1,00 \\
* *\end{array}$ & 0,00 & $\mathrm{a}$ \\
\hline
\end{tabular}


reproduce the results previously obtained with microfiltered milk. The results differed from those of Fweja et al. (2008), who reported the bacteriostatic effect against $S$. aureus of $\mathrm{H}_{2} \mathrm{O}_{2}$ combined with LP was $30 \%$ more effective than that of $\mathrm{H}_{2} \mathrm{O}_{2}$ alone. Lactoperoxidase has been found to exert a bacteriostatic effect on lactic acid bacteria, and a bactericidal effect on Gram-negative bacteria (Piard and Desmazeaud, 1991). S. aureus growth was delayed in milk with concentrations of LP from $5 \mathrm{mg} \mathrm{l}^{-1}$ (McLay et al., 2002; Fweja et al., 2008). In our assay, limiting amount of indigenous thiocyanate in milk may have hampered the biocidal activity of LP lying in the production of hypothiocyanite. On the contrary, LP reduced the inhibition of $S$. aureus by $L$. garvieae in pasteurized milk in a similar way as catalase did. Indeed, several studies have shown that in the presence of an excess of hydrogen peroxide, lactoperoxidase may react as a pseudo-catalase (Boots and Floris, 2006).

Thus, inhibition of CPS by $L$. garvieae in milk did not only depend on production of $\mathrm{H}_{2} \mathrm{O}_{2}$ by L. garvieae and was affected by synergistic or antagonistic factors such as milk indigenous lactoperoxidase system or catalase activities. Acidification was likely involved in the inhibition between 6 and 24 h, especially in raw milk. Involvement of bacteriocins or competition for nutrients in the inhibition of $S$. aureus by L. garvieae cannot be excluded. However, Alomar et al. (2008b) did not find any antistaphylococcal substances in the concentrated supernatants of cultures of $L$. garvieae N201. Also, competition for amino acids was not involved as addition of valine, isoleucine, threonine, methionine and phenylalanine did not suppress the inhibition of S. aureus by L. garvieae N201.

\subsection{Inhibition of CPS by L. garvieae and interactions with the microbial community in raw milk cheese}

Considering the potential antagonistic effect of raw milk microbial community on coagulase-positive staphylococci and L. garvieae, the efficiency of the inhibition of CPS by L. garvieae in raw milk cheese during cheese-making and ripening was examined.

Growth of CPS between 0 and 24h in raw milk cheeses was 1 log lower in presence of L. garvieae than in control cheeses (Table 4). Afterwards, CPS counts decreased and remained lower in cheeses inoculated with L. garvieae than in control cheeses at least up to 16 days of ripening.

The lactococcus count (Turner medium) was about 7.3 $\log$ CFU ml ${ }^{-1}$ in milk inoculated with L. garvieae (Table 4). It reached $8.2 \log \mathrm{CFU} \mathrm{m} \mathrm{m}^{-1}$ in cheese on day 1 and remained between 8.2 and $8.6 \log \mathrm{CFU} \mathrm{ml} \mathrm{m}^{-1}$ up to the end of ripening. L. garvieae population levels determined by quantitative PCR were higher than the counts on Turner medium, especially in milk with $8.7 \log \mathrm{CFU} \mathrm{m}{ }^{-1}$, and to a lesser extent in cheese $\left(8.6 \log \mathrm{CFU} \mathrm{m} \mathrm{m}^{-1}\right.$ on day 1 and 9 $\log \mathrm{CFU} \mathrm{ml} \mathrm{m}^{-1}$ on day 32). These discrepancies may be due to the fact that the QPCR analyses were performed on genomic DNA, allowing the detection of viable non-culturable cells and dead cells. L. garvieae was absent or below the detection level of the QPCR assay $\left(10^{4} \mathrm{CFU} \mathrm{ml} \mathrm{m}^{-1}\right)$ in control milk and control cheeses.

L. garvieae only grew on Turner medium, therefore counts on all other media were not affected by the presence of colonies of L. garvieae. Between the milk stage and 24 hold cheese, growth of Enterococci (SB), dextrane-producing Leuconostocs (MSE), Pseudomonas (CFC), mesophilic heterofermentative Lactobacilli (FH), Gram-positive catalase-positive bacteria and Enterococci (CRBM), and Enterobacteriaceae (VRBG) were all significantly lower in presence of $L$. garvieae. After that, counts of Enterococci remained by at least $0.6 \log$ lower in presence of $L$. garvieae up to day 32. Counts of Gram-positive catalase-positive bacteria, dextrane-producing Leuconostocs, mesophilic heterofermentative Lactobacilli, total Gram-negative bacteria (PCAI) and Enterobacteriaceae remained lower in presence of $L$. garvieae up to day 16 . Counts of yeasts (OGAL) were significantly lower in presence of $L$. garvieae on days 8 and 16.

The $\mathrm{pH}$ values in cheese were around 5.6 after $6 \mathrm{~h}$, and around 5.2 after $24 \mathrm{~h}$. No significant difference was found in presence or absence of $L$. garvieae. On day 1 , concentrations of D-lactate and acetate were very low $\left(<0.1 \mathrm{~g} \mathrm{~kg}^{-1}\right)$ and no significant difference was found in L-lactate concentrations (around $9 \mathrm{~g} \mathrm{~kg}^{-1}$ ) in presence v. absence of $L$. garvieae. Therefore, $L$. garvieae had no significant effect on acidification in cheese.

Despite the higher CPS count in raw milk used to make cheese $\left(\sim 3 \log \mathrm{CFU} \mathrm{ml}{ }^{-1}\right)$ compared with that in raw milk used for milk assays $\left(\sim 2 \log \mathrm{CFU} \mathrm{ml} \mathrm{m}^{-1}\right.$ ), the inhibition of CPS growth by L. garvieae in raw milk cheese over the first day was similar to that in raw milk $(\sim 0.8 \mathrm{log})$, but lower than that in pasteurized and microfiltered milks. Again, this may be due to a lower sensitivity of native CPS populations to $\mathrm{H}_{2} \mathrm{O}_{2}$. Alternatively, or in addition, it may be due to the activity of catalase-positive bacteria from raw milk, such as ripening bacteria (coryneforms, coagulase-negative staphylococci), which reached 4 to $5 \log \mathrm{CFU} \mathrm{g}^{-1}$ in cheese on day 1 . Although lactic acid bacteria are catalase-negative and generally sensitive to $\mathrm{H}_{2} \mathrm{O}_{2}$ (Rochat et al., 2006), most of them demonstrated various degrees of reactive oxygen species' scavenging abilities (Lin and Yen, 1999). Most LAB, such as Lactococcus lactis, express superoxide dismutase activity (Miyoshi et al., 2003).

L. garvieae had an early antagonistic effect not only on coagulasepositive staphylococci but also on the growth of several other microbial groups. This lastingly affected population levels and balance during ripening. These results support the hypothesis of a non-specific inhibition mechanism, as could be a nutritional competition or the production of $\mathrm{H}_{2} \mathrm{O}_{2}$ by $L$. garvieae. Hydrogen peroxide is known to have a rapid bacteriostatic/bactericidal effect on microbial populations, especially Gram-negative bacteria (Bjorck et al., 1975).

\section{Conclusion}

This study has not fully resolved the question of the nature of the inhibition of $S$. aureus by L. garvieae but the results support the hypothesis of a mechanism involving hydrogen peroxide or derivatives, which was effective within the first $6 \mathrm{~h}$ of culture. Acidification was likely involved in the inhibition between 6 and $24 \mathrm{~h}$ in raw milk. Inhibition of CPS by $L$. garvieae in milk may also be affected by milk indigenous hydrogen peroxide scavenging activities. In particular, the potential synergistic or antagonistic interaction of milk lactoperoxidase system on the inhibition, depending on $\mathrm{H}_{2} \mathrm{O}_{2}$ and thiocyanate concentrations, remains a hypothesis which deserves further investigations. Further work is also needed to understand the role of the microbial community of raw milk which may at the same time reduce $S$. aureus growth and interact with the inhibition by $L$. garvieae for example by producing catalase. Conversely, L. garvieae clearly reduced counts in several microbial groups in cheese on the first day and affected their dynamics during cheese ripening. In view of exploiting the antistaphylococcal activities of $L$. garvieae for the production of raw milk cheese, further investigation is needed to evaluate the consequences for the sensory properties of the cheese. However, the safety of $L$. garvieae N201 as a biopreservative strain in food should first be determined (Casalta and Montel, 2008). L. garvieae is a well-recognized fish pathogen (Vendrell et al., 2006) and is regarded as a rare, opportunistic pathogen of low virulence in human infections, responsible for scattered endocarditis (Li et al., 2008). However, Foschino et al. (2008) found a slight genetic relatedness between Italian dairy isolates and fish isolates. Fortina et al. (2007) showed that strains from dairy origin were characterized by a weak lactose acidifying 
capacity, which is absent in strains from fish origin, and generally by a low incidence of known virulence factors. Future research will explore genomic pathways for production of oxygen derivatives by L. garvieae and their potential role in S. aureus inhibition.

\section{Acknowledgments}

The authors sincerely thank Béatrice Desserre, Robert Didienne and René Lavigne for their technical assistance, and Harriet Coleman for proofreading of our English. This work received funding from TRUEFOOD, "Traditional United Europe Food", an integrated project financed by the European Commission under the 6th Framework Programme for RTD (Contract No. FOOD-CT-2006-016264).

\section{References}

Alomar, J. 2007. Etude de propriétés physiologiques de Lactococcus lactis et Lactococcus garvieae pour la maîtrise de Staphylococcus aureus en technologie fromagère, PhD dissertation, Institut National Polytechnique de Lorraine, Nancy.

Alomar, J., Lebert, A., Montel, M.C., 2008a. Effect of temperature and pH on growth of Staphylococcus aureus in co-culture with Lactococcus garvieae. Curr. Microbiol. 56, 408-412.

Alomar, J., Loubiere, P., Delbès, C., Nouaille, S., Montel, M.C., 2008b. Effect of Lactococcus garvieae, Lactococcus lactis and Enterococcus faecalis on the behaviour of Staphylococcus aureus in microfiltered milk. Food Microbiol. 25, $502-508$.

Arques, J.L., Rodriguez, E., Gaya, P., Medina, M., Guamis, B., Nunez, M., 2005. Inactivation of Staphylococcus aureus in raw milk cheese by combinations of highpressure treatments and bacteriocin-producing lactic acid bacteria. J. Appl. Microbiol. 98, 254-260.

Barnard, J.P., Stinson, M.W., 1999. Influence of environmental conditions on hydrogen peroxide formation by Streptococcus gordonii. Infect. Immun. 67, 6558-6564.

Barrett, N.E., Grandison, A.S., Lewis, M.J., 1999. Contribution of the lactoperoxidase system to the keeping quality of pasteurized milk. J. Dairy Res. 66, 73-80.

Batdorj, B., Trinetta, V., Dalgalarrondo, M., Prevost, H., Dousset, X., Ivanova, I., Haertle, T., Chobert, J.-M., 2007. Isolation, taxonomic identification and hydrogen peroxide production by Lactobacillus delbrueckii subsp. lactis T31, isolated from Mongolian yoghurt: inhibitory activity on food-borne pathogens. J. Appl. Microbiol. 103, 584-593.

Bjorck, L., Rosen, C.-G., Marshall, V., Reiter, B., 1975. Antibacterial activity of the lactoperoxidase system in milk against pseudomonads and other gram-negative bacteria. Appl. Environ. Microbiol. 30, 199-204.

Boots, J.-W., Floris, R., 2006. Lactoperoxidase: from catalytic mechanism to practical applications. Int. Dairy J. 16, 1272-1276.

Callon, C., Duthoit, F., Delbès, C., Ferrand, M., Le Frileux, Y., De Crémoux, R., Montel, M.C., 2007. Stability of microbial communities in goat milk during a lactation year: molecular approaches. Syst. Appl. Microbiol. 30, 547-560.

Casalta, E., Montel, M.-C., 2008. Safety assessment of dairy microorganisms: the Lactococcus genus: contribution to the safety assessment of technological microflora found in fermented dairy products. Int. J. Food Microbiol. 126 271-273.

Chassagne, M., Barnouin, J., Le Guenic, M., 2005. Expert assessment study of milking and hygiene practices characterizing very low somatic cell score herds in France. J. Dairy Sci. 88, 1909-1916.

Cole, J.R., Chai, B., Marsh, T.L., Farris, R.J., Wang, Q., Kulam, S.A., Chandra, S., McGarrell, D.M., Schmidt, T.M., Garrity, G.M., Tiedje, J.M., 2003. The Ribosomal Database Project (RDP-II): previewing a new autoaligner that allows regular updates and the new prokaryotic taxonomy. Nucleic Acids Res. 31, $442-443$.

Corsetti, A., Settanni, L., Braga, T.M., de Fatima Silva Lopes, M., Suzzi, G., 2008. An investigation of the bacteriocinogenic potential of lactic acid bacteria associated with wheat (Triticum durum) kernels and non-conventional flours. LWT. Food Sci. Technol. 41, 1173-1182.

De Buyser, M.L., Dufour, B., Maire, M., Lafarge, V., 2001. Implication of milk and milk products in food-borne diseases in France and in different industrialised countries. Int. J. Food Microbiol. 67, 1-17.

Denis, C., Gueguen, M., Henry, E., Levert, D., 2001. New media for the numeration of cheese surface bacteria. Lait 81, 365-379.

Duthoit, F., Godon, J.J., Montel, M.C., 2003. Bacterial community dynamics during production of registered designation of origin salers cheese as evaluated by $16 \mathrm{~S}$ rRNA gene single strand conformation polymorphism analysis. Appl. Environ. Microbiol. 69, 3840-3848.

Ferrier, L.K., Olson, N.F., Richardson, T., 1970. Analysis of hydrogen peroxide in milk using titanium tetrachloride. J. Dairy Sci. 53, 598-599.

Fortina, M.G., Ricci, G., Foschino, R., Picozzi, C., Dolci, P., Zeppa, G., Cocolin, L, Manachini, P.L., 2007. Phenotypic typing, technological properties and safety aspects of Lactococcus garvieae strains from dairy environments. J. Appl. Microbiol. 103, 445-453.
Foschino, R., Nucera, D., Volponi, G., Picozzi, C., Ortoffi, M., Bottero, M.T., 2008. Comparison of Lactococcus garvieae strains isolated in northern Italy from dairy products and fishes through molecular typing. J. Appl. Microbiol. 105 652-662.

Fweja, L.W.T., Lewis, M.J., Grandison, A.S., 2008. Challenge testing the lactoperoxidase system against a range of bacteria using different activation agents. J. Dairy Sci. 91, 2566-2574.

Gilliland, S.E., Speck, M.L., 1969. Biological response of lactic streptococci and lactobacilli to catalase. Appl. Microbiol. 17, 797-800.

Haeghebaert, S., Le Querrec, F., Gallay, A., Bouvet, P., Gomez, M., Vaillant, V., 2002. Les toxi-infections alimentaires collectives en France, en 1999 et 2000. Bull. Epidémiol. Hebdo. 23, 105-109.

Haines, W.C., Harmon, L.G., 1973. Effect of selected lactic acid bacteria on growth of Staphylococcus aureus and production of enterotoxin. Appl. Microbiol. 25, 436-441.

Ikeda, T., Tamate, N., Yamaguchi, K., Makino, S., 2005. Mass outbreak of food poisoning disease caused by small amounts of staphylococcal enterotoxins A and H. Appl. Environ. Microbiol. 71, 2793-2795.

Isolini, D., Grand, M., Glättli, H., 1990. Selektivmedien zum Nachweis von obligat und fakultativ heterofermentativen Laktobazillen. Schweiz. Milchw. Forschung. 19, 57-59.

Kamau, D.N., Doores, S., Pruitt, K.M., 1990. Enhanced thermal destruction of Listeria monocytogenes and Staphylococcus aureus by the lactoperoxidase system. Appl. Environ. Microbiol. 56, 2711-2716.

Kumar, R., Bathia, K.L., 1998. Standardization of method for lactoperoxidase assay in milk. Lait 79, 269-274.

Le Marc, Y., Valík, L., Medved'ová, A., 2009. Modelling the effect of the starter culture on the growth of Staphylococcus aureus in milk. Int. J. Food Microbiol. $129,306-311$.

Li, W.-K., Chen, Y.-S., Wann, S.-R., Liu, Y.-C., Tsai, H.-C., 2008. Lactococcus garvieae endocarditis with initial presentation of acute cerebral infarction in a healthy immunocompetent man. Intern. Med. 47, 1143-1146.

Lin, M.-Y., Yen, C.-L., 1999. Antioxidative ability of lactic acid bacteria. J. Agric. Food Chem. 47, 1460-1466.

Marty-Teysset, C., de la Torre, F., Garel, J.-R., 2000. Increased production of hydrogen peroxide by Lactobacillus delbrueckii subsp. bulgaricus upon aeration: involvement of an NADH oxidase in oxidative stress. Appl. Environ. Microbiol. 66, 262-267.

Mayeux, J.V., Sandine, W.E., Elliker, P.R., 1962. A selective medium for detecting Leuconostoc in mixed-strain starter cultures. J. Dairy Sci. 45, 655.

McLay, J.C., Kennedy, M.J., O'Rourke, A.L., Elliot, R.M., Simmonds, R.S., 2002. Inhibition of bacterial foodborne pathogens by the lactoperoxidase system in combination with monolaurin. Int. J. Food Microbiol. 73, 1-9.

Miyoshi, A., Rochat, T., Gratadoux, J.-J., Le Loir, Y., Costa Oliveira, S., Langella, P., Azevedo, V., 2003. Oxidative stress in Lactococcus lactis. Genet. Mol. Res. 2, $348-359$.

Ocana, V.S., de Ruiz Holgado, A.A., Nader-Macias, M.E., 1999. Growth inhibition of Staphylococcus aureus by $\mathrm{H}_{2} \mathrm{O}_{2}$-producing Lactobacillus paracasei subsp. paracasei isolated from the human vagina. FEMS Immunol. Med. Microbiol. 23, 87-92.

Otero, M., Nader-Macias, M.E., 2006. Inhibition of Staphylococcus aureus by $\mathrm{H}_{2} \mathrm{O}_{2}$ producing Lactobacillus gasseri isolated from the vaginal tract of cattle. Anim. Reprod. Sci. 96, 35-46.

Piard, J.-C., Desmazeaud, M., 1991. Inhibiting factors produced by lactic acid bacteria. Oxygen metabolites and catabolism end-products. Lait 71, 525-541.

Regev-Yochay, G., Trzcinski, K., Thompson, C.M., Malley, R., Lipsitch, M., 2006. Interference between Streptococcus pneumoniae and Staphylococcus aureus: in vitro hydrogen peroxide-mediated killing by Streptococcus pneumoniae. J. Bacteriol. 188, 4996-5001.

Rochat, T., Gratadoux, J.-J., Gruss, A., Corthier, G., Maguin, E., Langella, P., van de Guchte, M., 2006. Production of a heterologous nonheme catalase by Lactobacillus casei: an efficient tool for removal of $\mathrm{H}_{2} \mathrm{O}_{2}$ and protection of Lactobacillus bulgaricus from oxidative stress in milk. Appl. Environ. Microbiol. 72, 5143-5149.

Sanchez, J., Basanta, A., G $\leq$ mez-Sala, B., Herranz, C., Cintas, L.M., Hernandez, P.E., 2007. Antimicrobial and safety aspects, and biotechnological potential of bacteriocinogenic enterococci isolated from mallard ducks (Anas platyrhynchos). Int. J. Food Microbiol. 117, 295-305.

Simeao do Carmo, L., Dias, R.S., Linardi, V.R., Jose de Sena, M., Aparecida dos Santos, D., Eduardo de Faria, M., Pena, E.C., Jett, M., Heneine, L.G., 2002. Food poisoning due to enterotoxigenic strains of Staphylococcus present in Minas cheese and raw milk in Brazil. Food Microbiol. 19, 9-14.

Slanetz, L.C.W., Bartley, C.H., 1957. Numbers of enterococci in water, sewage and feces determinated by the membrane filter technique with an improved medium. J. Bacteriol. 74, 591-596.

Sommerhauser, J., Kloppert, B., Wolter, W., Zschock, M., Sobiraj, A., Failing, K., 2003. The epidemiology of Staphylococcus aureus infections from subclinical mastitis in dairy cows during a control programme. Vet. Microbiol. 96, 91-102.

Sutherland, J.P., Bayliss, A.J., Roberts, T.A., 1994. Predictive modelling of growth of Staphylococcus aureus: the effects of temperature, $\mathrm{pH}$ and sodium chloride. Int. J. Food Microbiol. 21, 217-236.

Terzaghi, B.E., Sandine, W.E., 1975. Improved medium for lactic streptococci and their bacteriophages. Appl. Microbiol. 29, 807-813.

Turner, N., Sandine, W.E., Elliker, P.R., Day, E.A., 1963. Use of tetrazolium dyes in an agar medium for differentiation of Streptococcus lactis and Streptococcus cremoris. J. Dairy Sci. 46, 380-385. 
Vendrell, D., Balcázar, J.L., Ruiz-Zarzuela, I., de Blas, I., Gironés, O., Múzquiz, J.L., 2006. Lactococcus garvieae in fish: a review. Comp. Immunol. Microbiol. Infect. Dis. 29, 177-198.

Villani, F., Aponte, M., Blaiotta, G., Mauriello, G., Pepe, O., Moschetti, G., 2001. Detection and characterization of a bacteriocin, garviecin L1-5, produced by
Lactococcus garvieae isolated from raw cow's milk. J. Appl. Microbiol. 90, 430-439.

Yang, X., Ma, K., 2005. Determination of hydrogen peroxide generated by reduced nicotinamide adenine dinucleotide oxidase. Anal. Biochem. 344 $130-134$ 